\title{
GIS-BASED PALEO-HYDROGRAPHICAL STUDY FOR TERRITORIAL DEVELOPMENT PLANNING OF THE RENO BASIN USING XVIII CENTURY ANDREA CHIESA HISTORICAL MAPS (BOLOGNA, ITALY)
}

\author{
Matteo Brusa, Michele Solmi, Gilmo Vianello, Livia Vittori Antisari
}

\section{Introduction}

From the XVI century, thanks to the studies on the cylindrical projection of the Flemish artist Gerard Kremer (1512-1594), better known under the pseudonym of Mercator, cartography assumed topographic value with representations based on precise measurements on a geodetic basis.

Indirect determination of distances and heights was obtained with the method of triangulation.

Giovanni Domenico Cassini (1625-1712) took advantage of this knowledge: during his long stay in Bologna as a professor of astronomy at Alma Mater Studiorum, he was also commissioned by the "Assunteria of Boundaries and Water" of the city to investigate issues concerning the Po and Reno rivers which had been under dispute for more than a hundred years by Bologna, Ferrara and Ravenna, whose interests had been damaged to varying extents by periodic floods and flooding, and even more by artificially produced changes in the course of the two rivers [Cassini 2003].

A series of autograph drawings of G. D. Cassini made between 1656 and 1660 and preserved at the Biblioteca Comunale of Ferrara Ariostea and the University of Bologna, clearly show the status of the water system of the territories of Bologna and Ferrara and plans for the diversion of some sections of rivers, including the channelling of the Reno into the Po Grande. Proposals made by Cassini were applied to a limited extent, unlike the writings and cartographic representations that were taken up by the hydrostatic expert Andrea Chiesa (1701 - ?) who, in 1731, together with his brother Pietro, was entrusted by the "Assunteria of Waters" to perform a survey of the entire Bologna plain using the method of plane tables [Giacomelli 1992]. Chiesa's cartographic production last-

Paper received 19.03.2010; accepted 20.08.2010

M. BrusA, Agronomist (matteo.brusa@unibo.it); M. Solmi, Agronomist (michele.solmi@unibo.it); G. VIANELlo, Full Professor (gilmo.vianello@unibo.it); L. VITTORI ANTISARI, University Researcher (livia.vittori@unibo.it). Department of Agroenvironmental Sciences and Technlogies, University of Bologna, via Fanin, 40-40127 Bologna, Tel. 051.2096202 - Fax 051.2096203 ed until 1762 and is part of the considerable innovation at that time in cartography at a European level, with characteristics similar to French topographic maps made by Jacques Cassini de Thury (1677-1756) based on projections and representations obtained with mathematical methods.

Thanks to the roads, hydrography, settlements, bridges and large aristocratic court details, the Chiesa maps are a fundamental tool for comparison with the current condition of the area and a modern reference to evaluate the transformations that have taken place in waterways [Brusa 2009].

\section{Andrea Chiesa maps}

At the beginning of the XVIII century the Bologna and Ferrara plains were affected by many hydrogeological disorder phenomena, due to the precarious hydraulic conditions of the waterways running down from the Apennines. These waters were not able to reach the Adriatic coast naturally, but stagnated instead in extensive unhealthy and unproductive marshes.

The Senate of Bologna and then-Pope, Benedict XIV, entrusted a land surveyor, Andrea Chiesa, to draw a detailed hydrographic map of the entire Bologna plain, in order to plan adequate territorial defence interventions. A. Chiesa belonged to the group of architects, hydrostatics, agronomists, and land surveyors authorized by a 1744 decree to practice such specialized professions.

The first maps were published in 1742, then extended in 1762 to include Ferrara territories, using a 2000 "pertiche bolognesi" triangular scale, equal to a numeric scale of 1:30'712.

The graphic work consists of 18 engravings $(50 \mathrm{x}$ $36 \mathrm{~cm}$ ) and two separate inscriptions: the first one includes the legend and the reasons for the work and the second one the dedication to Benedict XIV. Both inscriptions highlight the precarious hydraulic and environmental conditions afflicting the plain and its populations; the inability of embankments to contain waters during flood periods was also pointed out, with consequent inundations of lowlands and cultivated areas. 
The Andrea Chiesa "Carta della Pianura Bolognese" represented the starting point for the development of many hydraulic organization projects that were necessary, during the following two centuries, to implement full land reclamations [Cervelleti 1992].

\section{Methodology}

\subsection{Digital acquisition}

The maps used in this paper are copies of the original ones, part of the publication "La Carta della Pianura Bolognese di Andrea Chiesa, 1740-1742" printed in 1992 by Graphis Edizioni (Casalecchio di Reno, Bologna). The maps were scanned in high resolution (300 DPI) in digital raster format (TIFF), 16 colours. Due to the considerable dimensions of the papers $(60$ $\times 47 \mathrm{~cm}$ ) a professional flatbed scanner was used; despite being expensive, this method minimizes possible distortions [Here 2006].

\subsection{Georeferencing}

Each map covers an area of $205 \mathrm{~km}^{2}$, which is too wide to be processed as a single image: they were therefore split into four submaps which were individually georeferenced. This increases the superimpositions between the elements of the historical map and the ones on current topographic maps.

Widely-used software such as Environmental Systems Research Institute's (ESRI) ArcViewGIS 3.2 was chosen, as it possesses sufficient data input, digitizing, editing and analysis capabilities for the purposes of this paper. The georeferenced file is obtained using the nearest neighbour algorithm.

Arcview makes it possible to evaluate the Root Mean Square Error (RMS Error) in map units (metres, degrees...) and to establish the accuracy of the georeferencing process.
Minimizing the RMS Error is possible using a well distributed GCP set: the whole area, and in particular the perimetric zones must be covered uniformly. In this way, the image will not be patchy with precise zones (GCP-rich) and rough zones (GCP-poor).

In this particular case, the RMS obtained are about $80 \mathrm{~m}$ in the first stage and about $20 \mathrm{~m}$ in the second one. These results are satisfactory considering the age and the scale of the Chiesa maps.

Regardless of the original datum of the Stato Pontificio and Carta Topografica maps, it was decided to use the international UTM-WGS84 datum, which is commonly used in all fields of cartographical science and fully GPS-compatible, to facilitate the locating of any field analysis sites (e.g. soil profiling, archaeological investigation, rural and landscape survey...).

\subsection{Digitization}

The digitization campaign was carried out in different phases based on the typology of the elements considered:

- Waterways were digitized as polyline entities and the associated database reports the relative hydronyms. Due to the thinness of the waterways drawn on the Chiesa maps, it was not necessary to use polygonal thematism.

- Swamps and areas prone to flooding were digitized as polygonal entities and the associated database reports the relative hydronyms, where present.

- Rural settlements (scattered houses) were digitized as punctual entities and the associated database reports the relative toponyms, where present.

- Main urban centres were digitized as polygonal entities and the associated database reports the relative toponyms.

\subsection{Database compilation}

At the same time, a database was created that re-

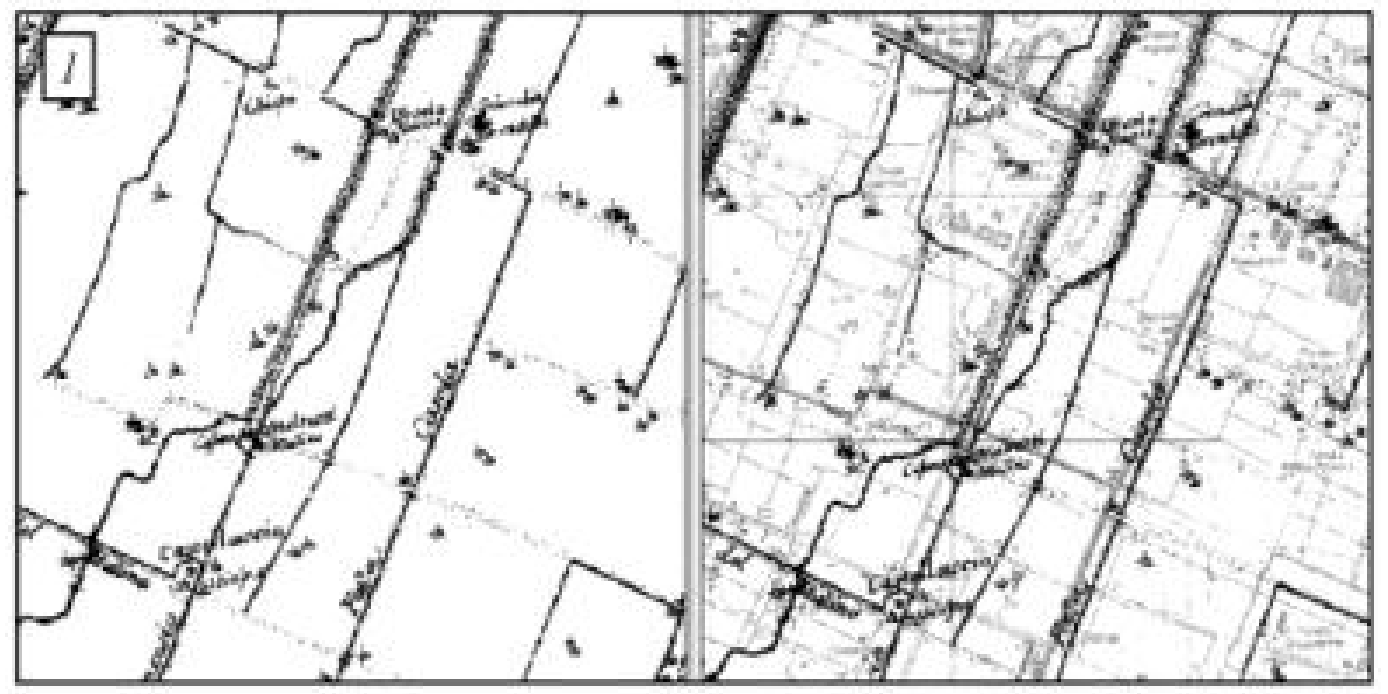

Fig. 1 - Second stage of georeferencing: on the right-hand side, a Chiesa map is superimposed on the Emilia Romagna topographic map (rough georeferencing errors are clearly visible). 


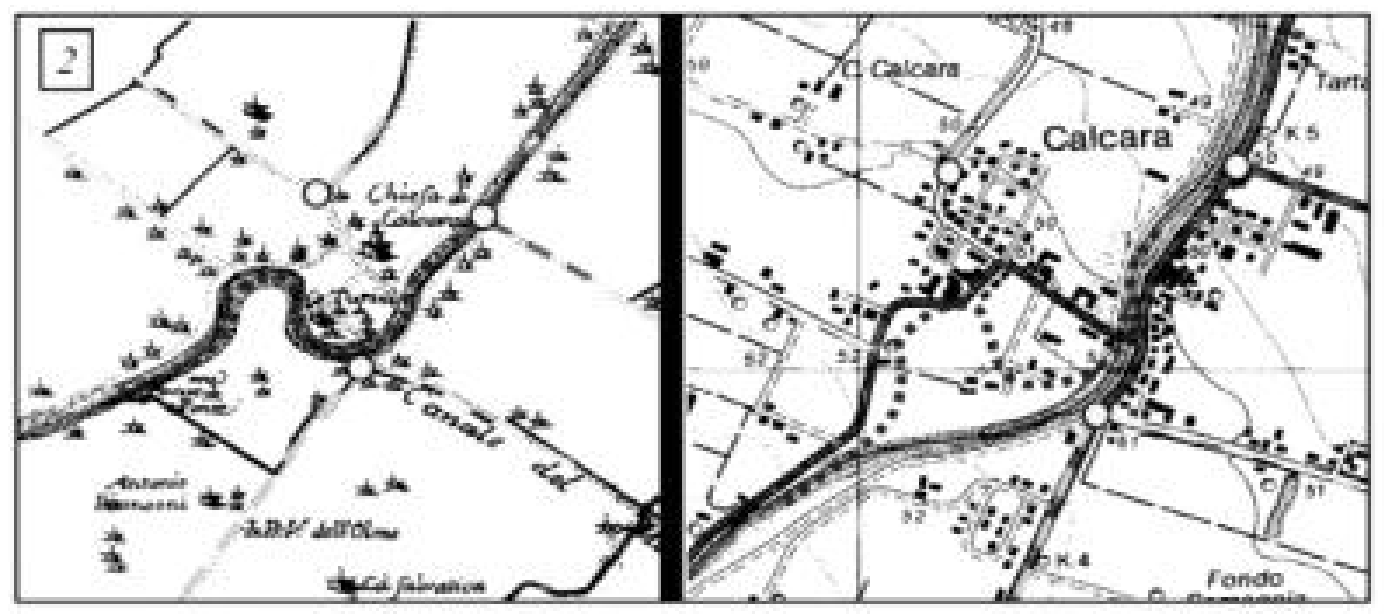

Fig. 2 - Calcara (Calderara di Reno - BO): GCPs (yellow dots) choice based on territorial elements persistence.

ports as accurately as possible all the information we found in the Chiesa maps; this made it possible to combine each territorial element with the relative notions such as toponyms of the main hydrographical (rivers, torrents, streams), morphological (embankments, lowlands) and anthrophyzed elements (roads, bridges, urban centres) [Orciani 2007].

This database provides an interesting perspective for research into the origin of the toponyms of the period and the connection with geological and flauravegetation features of that time.

\section{Research fields suggested by the Chiesa maps}

The residential tissue is clearly divided into two typologies based on the settlement's density:

1. Urban centres: only the borders, often represented by city walls, are properly sketched with actual proportions; the inner part of the towns are filled in with a jumble of small houses, without any correspondence with the actual buildings. This is not considered as a limitation of these maps, but as a consequence of the main purpose and the scale of

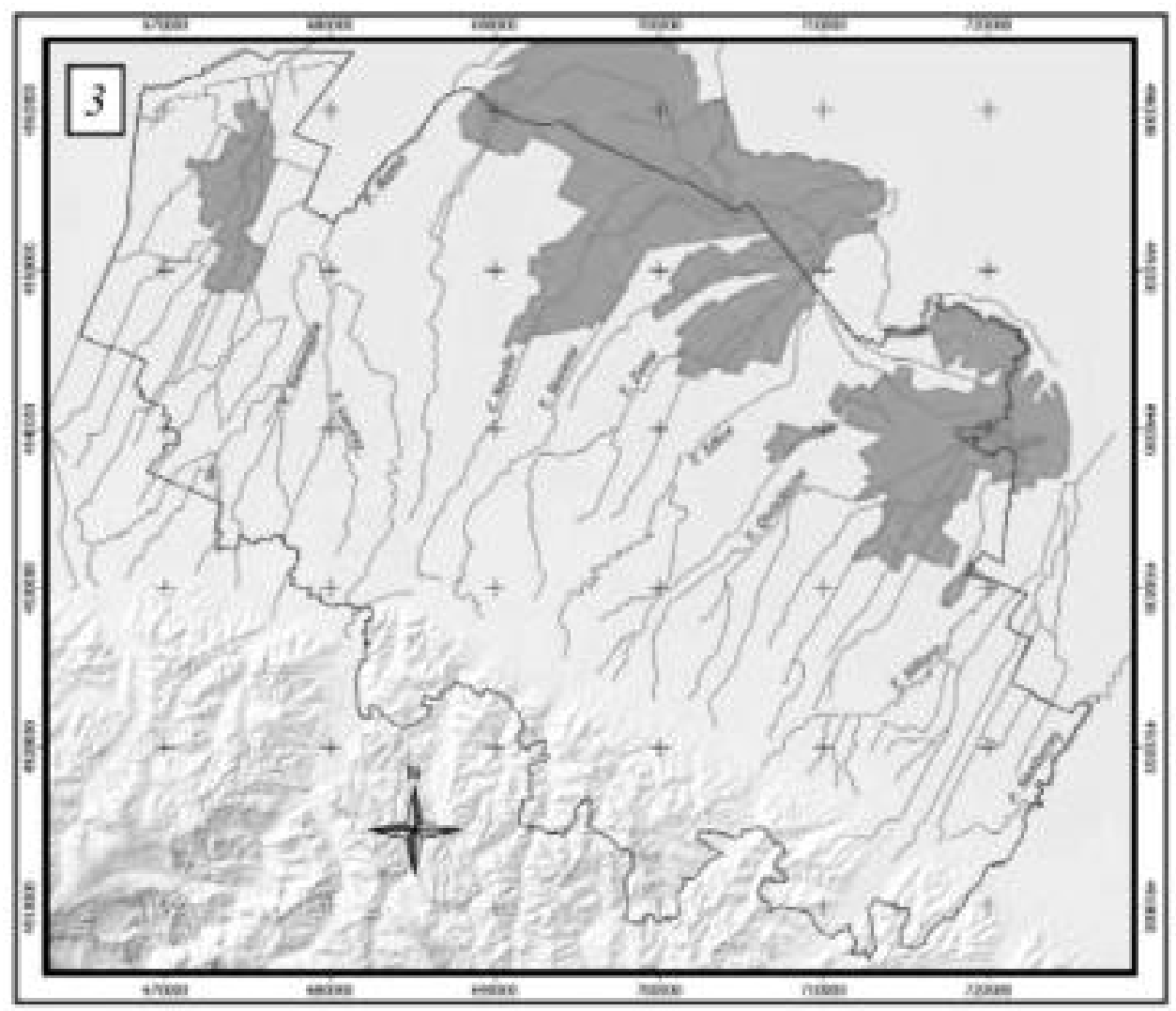

Fig. 3 - Map result of the digitalization of the Chiesa maps, reporting the main plain waterways of 1742. Blue areas are permanent or temporary marshes. 
the representation, too small to allow a cadastrial explanation of buildings.

2. Scattered houses are identified with "fumanti", the inhabitants registered at the cadastre paying possession taxes. Fumante means "smoking" and stated the presence of a fireplace, thus a house. Firstly, there was a biunique correspondence between fumanti and buildings, but, since a fumante stated only the payment of a tax, in the following decades the correspondence declined, and nowadays it is not always possible to find a building in a place described as fumante.

The residential system is a very important theme in the planning; this paper focuses on the rural territory, since it is closely linked to the economic transformations of the region and alternations of large landowners and sharecroppers in the agricultural management. Three centuries of mutations have deeply shaped the structure of landholdings and settlements to a considerable extent.

\subsection{Historical Toponyms and etymology studies}

The etymological study of the former toponyms adds great value to the drawn maps, indeed it makes it possible to understand the historical environmental context of the represented sites [Solmi 2010]; some examples are reported:

1. Morphological information: Fiesso (from the Latin Flexus meaning bend - an ancient turn of the Idice Torrent), Marmorta (means a place where the sea dies - brackish swamp), S. Martino in Argine (because of the presence of the embankment close to the S. Martino settlement), Traghetto (ferry which carried people across the marsh).

2. Arboreal information: Molino della Pioppa (Mill close to a very large poplar, Populus spp.), Chiesa
dell'Olmo (Elm Church, Ulmus campestris), Convento del Melo (Apple tree convent - Malus spp).

3. Archaeological information: Chiesa delle Tombe (Tomb church).

\subsection{Hydrographical network and relationships with micromorphology}

A further contribution provided by the Chiesa maps concerns the relationships between former hydro-morphological conditions and current characteristics of the soils.

Figure 6 shows a portion of the territory of the Bologna and Imola middle and lower plain, affected by the action of the Idice and Sillaro streams as described in the Chiesa maps and in the recent Regional Soil map. The north-eastern part of the Chiesa maps shows the extensive areas subject to strong flooding, which are graphically expressed by the words: "Valleys", "Land that flooded", "Grass that flooded", "Wood which flooded".

Moreover, some other places are highlighted for their agricultural activities, "Arable with grapevine", "Grass and arable terrain with grapevine", as indicated to the north and west of Molinella. Soils present in the same area can be grouped into three types of geolandscape, depending on the behaviour of the Apennine water courses and the way the sedimentation took place, and on anthropic activities that were carried out through the centuries. There is full correspondence between the geo-landscape of morphologically depressed areas and valleys and marshy areas represented in the Chiesa maps [Vittori Antisari 2005].

The digitalization of the drains, ditches, torrents and rivers of the Chiesa maps allowed the comparison with the present hydrological network, noting all the variations and analyzing the main phenomena that led to such variations. In this context the morphology and
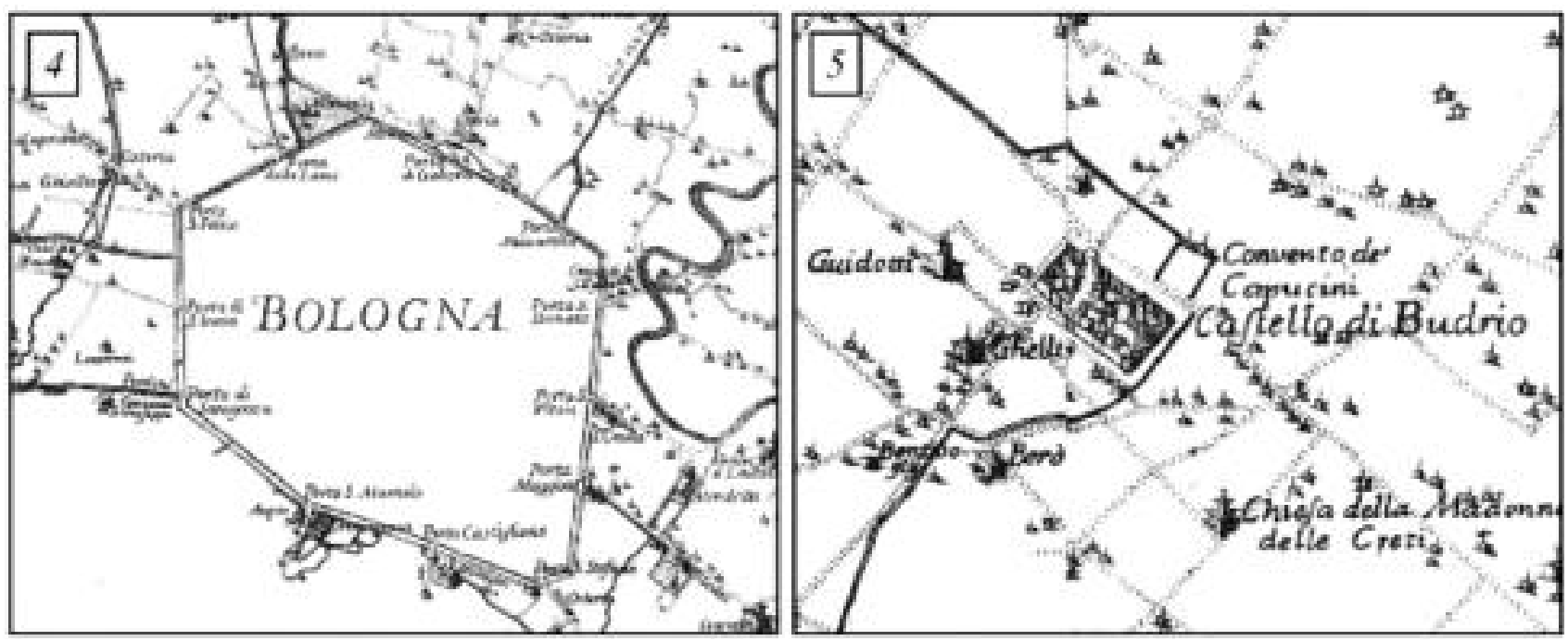

Figg. 4-5 - On the left, Bologna urban centre, represented only with city wall borders; on the right, Budrio urban centre, in which the houses located within the city walls are represented. 


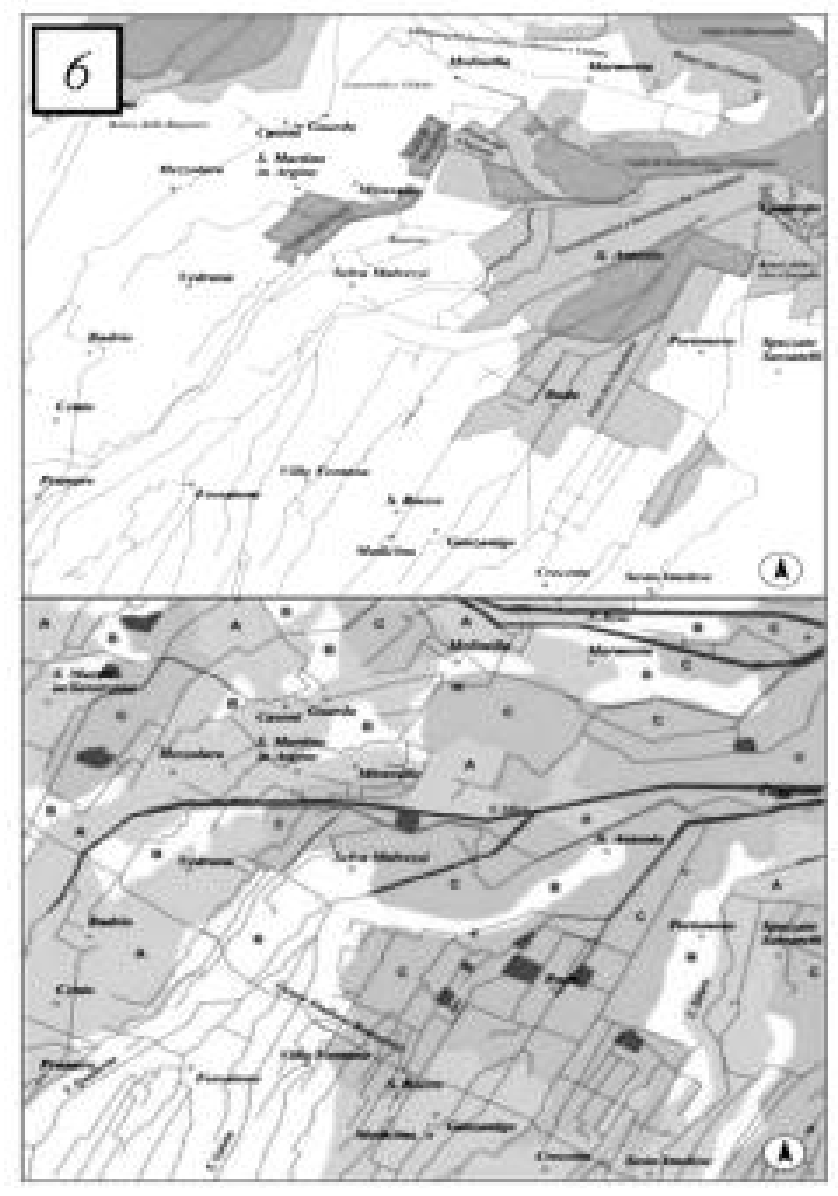

Fig. 6 - Comparison between the hydrography shown in the Chiesa maps and current geo-landscape characteristics: (top) Bologna and Imola plain representation: light blue indicates permanently flooded areas, green indicates periodically flooded areas;

(bottom) Geo-landscapes that allow a significant comparison with the former hydrographic system, with particular reference to ancient flooded areas (low and clayey) and embankments ( in relief and silty and sandy)

Geo-Landscape:

A - Topographically elevated areas corresponding to distal portions of alluvial conoids and to Roman Age neglected embankments of the Reno river and the Savena, Idice and Sillaro streams. These areas are characterized by loam and silt-loam soils.

B - Junction between elevated al low areas (embankments of the Quaderna, Centonara and Gaiana streams) characterized by silt clay loam soils.

C - Topographically low areas with a narrow and elongated shape within rivers or characterized by a wide and closed shape belonging to the low plane zone.

the territorial management have gained particular importance: they have conditioned the landscape over time, with considerable repercussions on the configuration of the hydrographical network. It should be noted that the cultivation model in the XVIII century was closely connected with the local hydrographical management. In particular, an assiduous and regular presence of farmworkers in the fields allowed continuous monitoring and at the same time all the lands were cultivated, including those with a moderate slope [Brumana 2007].

In the last few decades many cultivated fields have been abandoned; the hydrographical network development has been conditioned mainly by the territorial morphology [Orciani 2007].

\subsection{Centuriation}

In the Etruscan age, and then in the Roman age, massive drainage works were implemented upstream and downstream of the Via Emilia to allow the establishment of a large rural population; this made it necessary to regulate waterways running down from the Apennines with a complex system of ductworks, which suited the orthogonal Roman centuriation and is still visible in some places.

From the second century BC, the Romans imposed a regular pattern on the territory, which materialized in the road system, construction and renovation of municipal facilities, the design of the waterway network, the streamlining of procedures for managing agronomic soils and reclamation of vacant lands, and the regulation of the criteria to allocate land to settlers [Dall'Aglio 1999].

\begin{tabular}{|l|r|}
\hline Surface of the Bologna province $\left[\mathrm{km}^{2}\right]$ & 3703.0 \\
\hline $\begin{array}{l}\text { Surface covered by the centuriation layout } \\
\left(2^{\text {nd }} \text { century B.C. }\right)\left[\mathrm{km}^{2}\right]\end{array}$ & 1353.8 \\
\hline $\begin{array}{l}\text { Surface covered by the centuriation layout } \\
(1742)\left[\mathrm{km}^{2}\right]\end{array}$ & 712.3 \\
\hline Variation $[\%]$ & -47.4 \\
\hline
\end{tabular}

\subsection{Hydrogeological risk mapping}

The existing hydraulic system of the lower plain is characterized by rivers that have been rectified and contained within artificial embankments that are considerably elevated over terrain level; by overlaying the existing network on the Chiesa maps and micromorphology maps of the territory, it is possible to create hydrological risk maps.

It is clear that morphologically depressed areas and those identified as periodically or permanently inundated, and traversed by this anthropic waterways system are under a high risk of flooding if the embankments break.

\section{Popularization opportunities}

Research and studies based on historical maps could be extremely interesting and useful in terms of territorial planning and for in-depth understanding of the evolution of an area, but the interest of the entire work could be put in jeopardy if not properly popularized. The opportunities created by publishing such historical information on an internet portal can turn an insider's interest into widespread knowledge.

To summarise, various disciplines are involved in this work:

- Geo-pedology: a knowledge of former waterways 


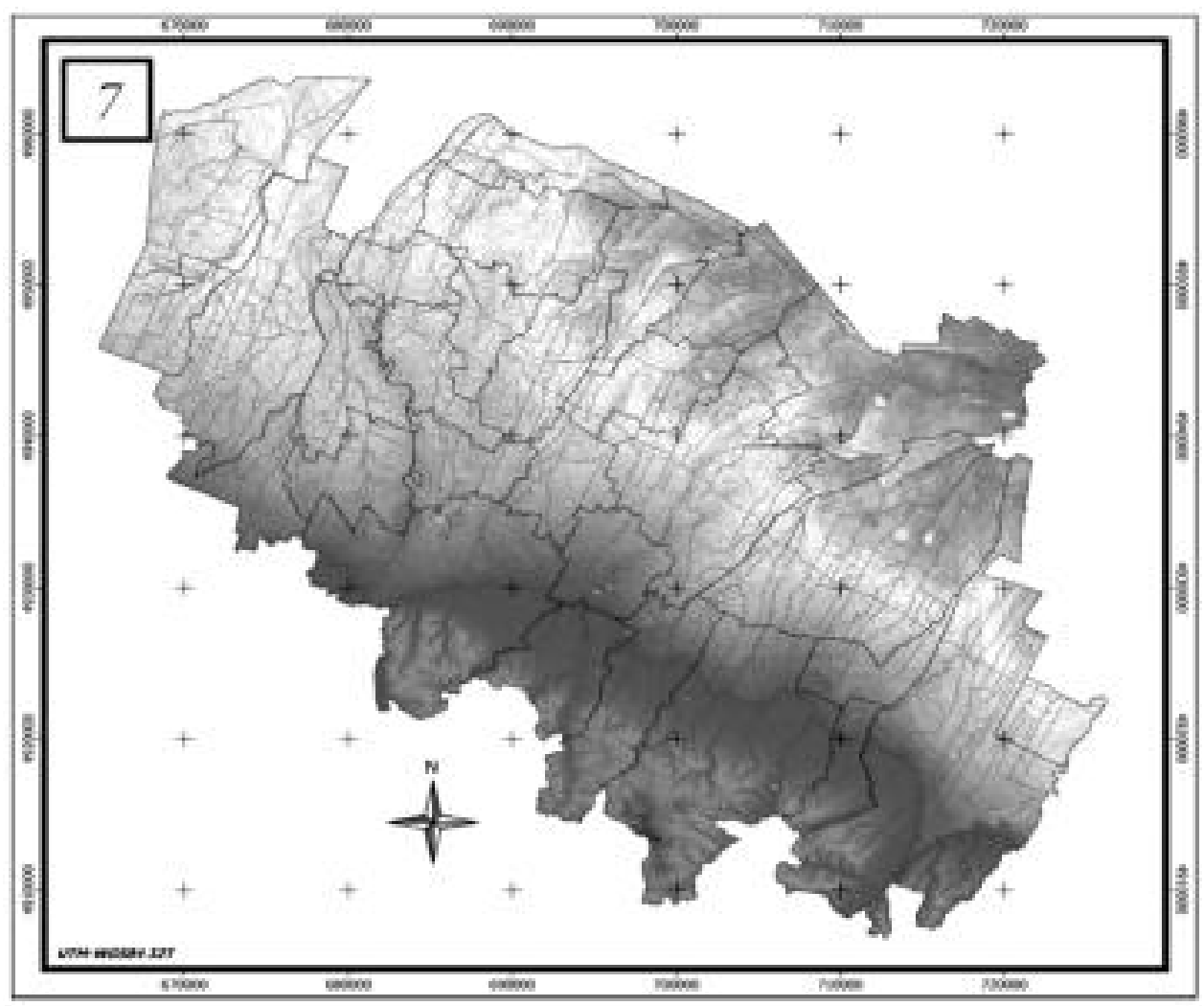

Fig. 7 - Map result of a micro-morphology DEM elaboration of Bologna plain. Green areas are lowest ones.

and geomorphology helps to understand the evolution and the meaning of particular kinds of soils, e.g. closely linked to a no longer present marsh or waterway, such as vertisols and gleysols.

- Town-planning: insiders could take advantage of these data to:

- Valorise and protect territorial invariants and typicalities such as the centurial texture and historical routes;

- Prevent hydrogeological risk by avoiding constructions or planning more carefully in lowlands and in proximity to paleochannels: in the event of flooding these areas are likely to be the first to be submerged.

- Agronomy: generally, the Chiesa maps show no indications regarding the main crops, but many indications about the products of marginal areas have been found; in proximity to wetlands it is possible to find "bosco che si inonda" (wood that floods), "prato inondato" (wet meadow). Agronomy, in synergy with pedology, can investigate the vocation of certain areas.

- Archaeology: these maps are used to locate possible archaeological sites; the most important map elements that can be used are buildings and settlements.

- Toponymy: this has to do with research on topographical names. In addition to land use, most researchers use this element. It is also possible to detect local language evolution.

- History and teaching: knowledge of local history is an important cultural value and could be used as a powerful teaching tool.

This kind of popularization allows a large variety of specialists and lay people to compare the different cartographic (historical) layers one to another, such as streets, former and current hydrology, toponyms, land use, rural settlements, over current topographic maps and aerial photographs. This makes it possible to evaluate territorial texture mutations and permanencies and the pleasure of discovering traces of the past in the normality of the daily landscape [Pearson 2007].

\section{Conclusions}

Andrea Chiesa maps represented a revolutionary moment in the knowledge of the Bologna area, linking science to the government of the waters. Maps formed the basis for land reclamations of the following decades. These maps represented the technical basis of the projects that led to the definitive channeling of the Reno river into the Po di Primaro and the start of full land reclamation.

A. Chiesa is among the great innovators of cartography in Europe, and his maps can indeed be considered as modern cartography in which he combined the skills of the geographer and chorographer; he divided the nature from the land and the water; he drew artifacts and streets, designing a true legend which created typological symbols of houses and buildings. The set of signs, symbols, places and toponyms of topo- 
graphic organization anticipated the modern cartography that developed in the second half of the eighteenth century in France, then spread throughout Europe in the nineteenth century.

The information contained in this document provides valuable knowledge of the ancient land, enabling comparisons and judgments about the transformations which the Bologna plain underwent over three centuries; this comparison becomes objective and can be applied to the latest computer techniques, thanks to the metric precision and geographic positioning used in the making of the maps.

Nowadays, Chiesa maps still have a great value: they represent a powerful instrument for territorial development planning, since the hydrological information they contain can be used to direct urbanization policies (e.g. avoiding urban/industrial expansion in areas formerly occupied by swamps, evidently located in lowlands).

In an attempt to reconstruct the evolution of the agricultural landscape, which is an expression of the economic, cultural and technological context, this method proves itself to be globally integrated with life and the work of man [Solmi 2010].

On a territorial scale, waterways represent the most important and widespread natural network: Chiesa maps help to consider the environment from a historical and ecological point of view at the same time.

Finally, the former road network traces the centuriation texture and an indelible sign of Roman interventions and the frame of the Bologna plain landscape; protection of these elements is a must to avoid the denaturation of a territory with several thousand years of history.

\section{References}

Brumana R., Achille R., Georeferencing as availability of space-temporal data: hstorical cartography towards advanced 3D view, e-Perimetron, 2007, Vol. 2, No. 3.

Brusa M., Gherardi M., Mezzini E., Solmi M., Vianello G., Vittori Antisari L., Evoluzione ambientale e territoriale. In Immagini del mondo rurale nello spazio e nel tempo: trasformazione dei territori rurali bolognesi ed imolesi di pianura e di collina dal 1700 ad oggi, Accademia Nazionale di Agricoltura, Ministero per i Beni e le Attività Culturali, 2009.

Cassini A., Domenico Cassini Uno scienziato del Seicento, 2nd Ed., Comune di Perinaldo, 2003.

Cervellati P., Venturi S., Dalla geografia e la corografia al piano: la carta di Andrea Chiesa. In La carta della pianura bolognese di Andrea Chiesa 1740-1742, Grafis Edizioni Bologna, 1992.

Dall'Aglio M., Il paesaggio agrario e le sue trasformazioni. In M. Montanari, M. Ridolfi and R. Zangheri Storia del-
l'Emilia-Romagna, Vol. 4, pp. 1-19, Editori Laterza, 1999.

Here E., The use of GIS with property maps, e-Perimetron, 2006, Vol. 1, No. 4.

Orciani M., Frazzica V., Colosi L., Galletti F., Gregoriano Cadastre: transformation of old maps into Geographical Information System and their contribution in terms of acquisition, processing and communication of historical data, e-Perimetron, 2007, Vol. 1, No. 2.

Pearson A.W., Digitizing and analyzing historical maps to provide new perspectives on the development of the agricultural landscape of England and Wales, ePerimetron, 2007, Vol. 1, No. 3.

Solmi M., Brusa M., Gherardi M., Vianello G., Gabrei historical maps and remote sensing technologies to understand landscape evolution and preserve rural invariants and typicalimes (Bologna Province, Italy). $5^{\text {th }}$ International workshop on digital approaches in cartographic heritage, IGA, Wien 22-24 February, 2010.

Vittori Antisari L., Delineazioni pedologiche e qualità del suolo. In Valli di Zena, Idice e Sillaro Percorsi nel tempo tra storia e realtà, pp. 75-80, Gruppo di Studi Savena Setta Sambro, Bologna, 2005.

\section{SUMMARY}

This paper focuses on the use of GIS with historical maps of the Bologna plain. A. Chiesa was entrusted, in 1732, by the Senate of Bologna to create a geographical map of the entire plain, with particular reference to the waterways, in order to provide an overall view and to plan considerable land reclamation.

After digital acquisition, the maps were georeferenced in a new two-stage technique, using the international UTM-WGS84 datum. The elements contained in the maps were digitized using different layers: points for settlements, polylines for the waterways and polygons for marshes. A database was created to complete the digital representation.

These data were compared with the current hydrographic situation. The main interest is the understanding of the relationships between paleochannels and micromorphology, in order to prevent hydrogeological risk.

The study of the A. Chiesa maps is important to understand the evolution of toponyms, to highlight the centuriation and as a decisional support in territorial development plans.

The popularization of the digitally obtained layers over a topographic regional map must be carried out using a webGIS application that is accessible and immediately understandable by the general public.

Keywords: historical maps, GIS, UTM-WGS84, georeferencing, hydrography, digitization, paleochannels. 
